\title{
Methods used in personnel audit in companies operating in the Slovak Republic in the stage of Industrial Revolution 4.0
}

\author{
Natália Matkovčíková, 1 \\ ${ }^{1}$ Faculty of Business Management, Department of Management, University of Economics in \\ Bratislava, Dolnozemská cesta 1/b,852 35 Bratislava, Slovak republic
}

\begin{abstract}
The present paper contains the results of a research carried out in the framework of the VEGA project $1 / 309 / 18$. Its aim was to identify and classify methods and approaches used in personnel audit in companies operating in the Slovak Republic in the stage of Industrial Revolution 4.0. to obtain objective information on compliance with legal standards and established standards for personnel work in the company in two areas: human resources and human resources management. The paper contains an analysis and description of the changes that have occurred in the companies with the onset of the Industrial Revolution 4.0 and the progress that these changes brought about in the repertoire of methods and approaches used in personnel audit. Key words: personnel audit, stage of industrial revolution 4.0, methods of personnel audit.
\end{abstract}

\section{Introduction}

The onset of industrial revolution 4.0 is the result of three interrelated and conditional processes. On the one hand, it is a process of globalization whose deepening breaks the regional borders of the labor markets and affects the symmetry on the labor market in favor of the demand for quality and prepared employees, thus starting the process of labor migration. On the other hand, it is a deepening process of internationalization that aims to create an international culture through the elimination of cultural and human differences, the labor force that enters the labor market and companies and brings an element of cultural heterogeneity into the working environment. Last but not least, it is mainly a massive entry of information and communication technologies into social processes and thus also inhouse environment, which besides opening the space for changes in in-house communication in all directions, vertical and horizontal. This significantly influences the processes of management and leading of employees in the company, they changes the content of work and thus also the requirements for physical and mental potential/preparedness of employees for work performance (performance potential) [1]. These three processes also significantly affect the approaches and methods used in the personnel audit. In the period prior to the onset of the Industrial Revolution 4.0, the personnel audit mainly used simple mathematical statistical methods aimed at assessing

\footnotetext{
${ }^{1}$ Corresponding author: natalia.matkovcikova@gmail.com
} 
administrative processes taking place in the field of personnel work $[2,3,4]$, at the stage of the fourth industrial revolution these methods are no longer sufficient to respond to the needs of companies expecting a personnel audit. Progress in the content of personnel work from administrative to operational [5] caused the need to extend the repertoire of used methods in personnel audit. Companies that have entered the fourth stage of the Industrial Revolution expect the personnel audit to answer questions that can no longer be answered on the basis of information obtained by basic statistical mathematical methods. They need information on streamlining the management of personnel processes in the company, information on the selection of quality employees for the company and also issues related to retaining employees in the company. These requirements could only be met by using additional methods in the personnel audit. In addition to the basic methods used to obtain static knowledge of employees, their age, gender and practice, psychodiagnostic methods began to be used in the personnel audit during this period, in particular methods to identify the employee's working ability and to identify his/her ability to learn new technology, to acquire new skills resulting from the introduction of information and communication technologies into the work process. These methods were and are primarily oriented on the evaluation of the human capital quality of the company [6]. Personnel audit is understood as a tool for streamlining the management of personnel processes in the company and also as a tool for determining the value of the company that can enter into the business valuation processes in the case of prepared fusions and the like [7]. During this period, personnel audits in various industries are starting to use mainly methods using electronic and digital media as well as non-standard methods to respond to the identification of new phenomena in the workforce behavior caused by these changes in the work environment and work process. The basic methods, which have not ceased to be used in the personnel audit, are also being transferred to the electronic form, but on the contrary they have increased their share in the method repertoire at this stage. The methodological approach and the process of personnel audit thus combine the basic and psychodiagnostic methods, which meets the needs of companies that close themselves during this period and focus on strengthening the personnel management operation $[8,9]$. "Personnel work in this period is characterized by the motto: the right people in the right place. It is the beginning of a new phase of personnel work, which in theory is called the phase of personnel management. Its content is "personnel insight into the company interior", focusing on operational management of personnel processes within the company. It is a stage that is characterized by the establishment of personnel departments and personnel managers, which are expected to stabilize/retain staff in the company, minimal personnel rotation, adherence to age automation in the evaluation of employees. This motto is also reflected in the basic objectives of personnel audit and also determines in the personnel audit the selection and application of methods and procedures" [3, p.63].

The main task of the personnel audit at this stage is to identify and characterize the mental and physical potential of the staff, which is referred to as "human capital" $[10,5,14$, 15]. As a result of several personnel audits carried out in companies during this period, it was found that psychodiagnostic methods were used the most [20] and were oriented to the determination of flexibility of the adaptation mechanism of employees, the ability to adapt their work stereotypes, work habits and attitudes to change [16, 17], triggering an increasingly massive entry of ICT into work processes. Concentrating on the use of these methods in personnel auditing has essentially been divided into a workforce that accepts and adapts to the changes these technologies bring to the work process and a workforce that is passive to rejection of ICT and is not able to adapt to this change. The preference of using these methods in the personnel audit led, according to some authors, for example J. Arnold et al.,[6], to some reduction of its goals and tasks and consequently to meeting the needs of companies. At the same time, some authors drew attention to the importance of the 
choice of methods and their possible combination in relation to the objectives of personnel audit and at the same time to the development stage in which the company and the personnel work carried out there are. In this context, for example M. Vetráková, [5] J. Anglim, V. Sojo, L. J. Ashford et al. [11] and other authors draw attention to the fact that personnel administrative activities are still in some percentage part of all activities in the field of personnel work and therefore the personnel audit cannot ignore the methods that quantify them. On the contrary, the results achieved by these methods point to reserves and sometimes also to the developmental stage of personnel work and indicate the need for changes $[18,19]$ in the company's personnel policy.

\section{Results of the Research and Discussion}

Based on the above, the basic objective of the research was formulated: to identify and characterize the methods that were used in personnel audit in companies operating in the Slovak Republic. The basis of the research was the main assumption that the main focus of the activities of personnel managers, personnel units, human resources units in companies operating in the Slovak Republic is mainly operational personnel activity, which corresponds to the developmental stage of personnel work in the stage of industrial revolution 4.0. At the core of operational work of personnel work should be three basic processes: recruitment and selection of employees, training of employees and stabilization/retention of employees in the company. Quality assurance of these processes depends on the systematic collection and evaluation of information and knowledge about their course and the reuse of the acquired information to improve it and the removal of reserves and deficiencies for which the personnel audit serves. Therefore, the main objective of secondary research was to systematize current knowledge of methods used in personnel audit and to find out in primary research what methods and procedures in personnel audit are used in companies operating in the Slovak Republic in which the personnel audit was performed.

The object of the research was a personnel audit in small, medium and large companies operating in the Slovak Republic. The subject of the research was the methods used in the past and now by companies in the personnel audit. The research sample consisted of 112 randomly selected respondents who performed a personnel audit in 445 companies operating in the Slovak Republic within 1 - 3 years. The research included only external and internal auditors who performed a personnel audit in the interviewed companies and had the necessary certificates (accreditation) that authorized them to carry out the personnel audit and also disposed the skills and competencies required to perform the personnel audit.

A questionnaire containing 30 combined questions was used to collect data and information. The questionnaire was distributed electronically. When sorting and processing the information and data obtained was used funnel-shaped procedure ${ }^{2}$. All 112 respondents responded to the questionnaire. The relevant answered questionnaires were 108. The structured interview method was also used to fill in the missing and inaccurate information, resulting in a $100 \%$ return. In addition to the above methods, methods of content analysis, synthesis, classification, comparison as well as statistical mathematical methods were used. These methods were also used to process the sets of methods used by the auditors in the personnel audits carried out by the companies surveyed by us. Standard quantitative and

\footnotetext{
${ }^{2}$ Note: The funnel procedure was based on our experience that respondents would respond positively to questions even if they were reluctant to disclose the methods they used in the personnel audit (copyright contradiction, recruitment agency know-how, etc.). This assumption has been confirmed.
} 
qualitative methods were used to collect, process, evaluate and interpret the data. The research was conducted in October - December 2018.

Whereas previous research and case studies to identify methods and procedures used in the personnel audit have drawn attention to the fact that auditors and personnel auditing personnel managers in the personnel audit use mainly non-standard methods in addition to the standard methods and select them so that confirmed the predetermined expectations, we assumed that this approach would be confirmed in our research as well. However, the results obtained did not confirm this assumption. The interviewed respondents used the entire repertoire of basic methods in the personnel audit, including exploratory and statistical methods (Figure 1). All the methods used were standardized and auditors were able to handle them. In conducting personnel audits in subsidiaries of multinational corporations, the auditors used methods and procedures developed by the parent companies to varying degrees to adapt to the domestic/Slovak legislative environment and cultural behavior patterns. In particular, the basic methods and procedures used by the auditors in the personnel audit were based on standard methods or procedures respectively these were modified standardized methods. For example, in some test batteries the extend was adjusted, questions that contained a cultural conflict or contradicted the customs of the country in which the subsidiary operated were omitted. In the overall set of methods used in the personnel audit, standard basic methods were used, mainly in paper form, which were combined according to the needs of the personnel audit client by standard psychodiagnostic methods. Only 28 respondents in 68 companies used a combination of basic and psychodiagnostic methods in the personnel audit. The psychodiagnostic methods were used mainly test batteries focused on the detection of intelligence, memory and inventory of personality traits. All test batteries were used with the participation of a psychologist. Only 6 respondents stated that they also used non-standard diagnostic methods mainly in connection with obtaining information from social networks in order to assess one of the components of the intellectual capital of the company - social capital. The results of the research show that the methods used in the personnel audit reflect the nature of the development stage, which is characterized by the concentration of personnel work on "human capital", exclusively on one of the components of intellectual capital and not on the intellectual capital of the company as a whole. This point is pointed out by several authors (J. Dušek,[12], M. Vetráková, [5] and others).

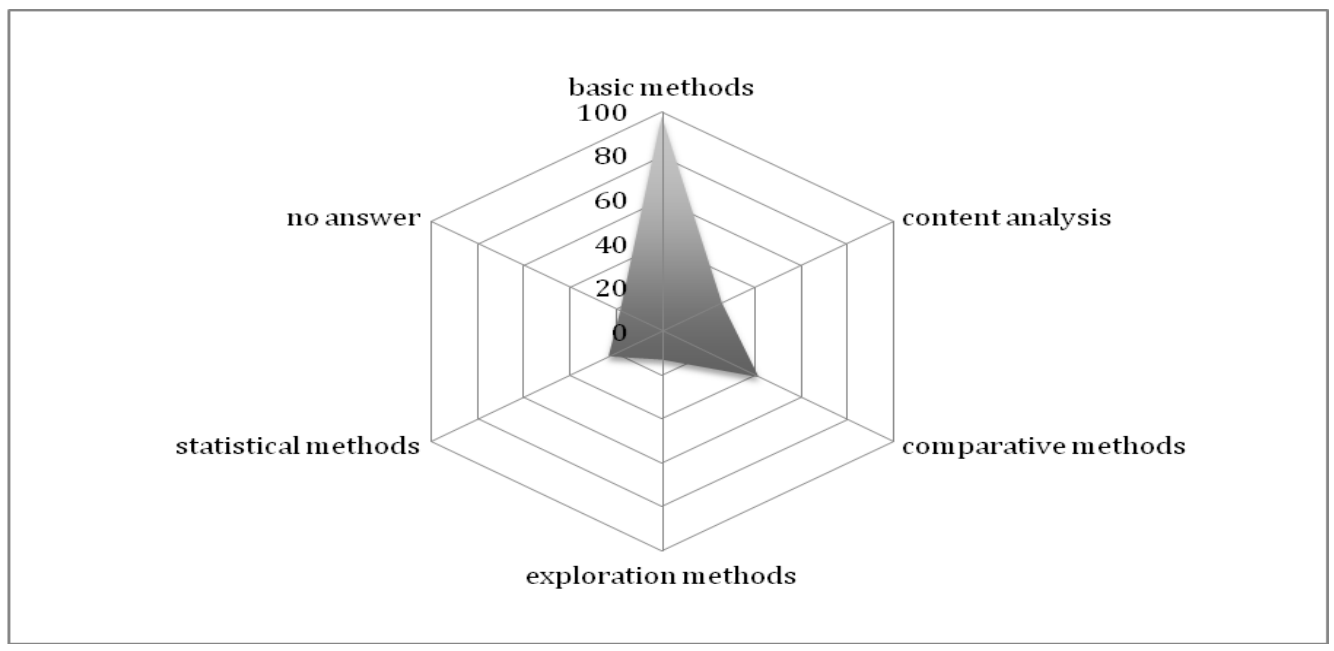

Fig. 1. Methods used in the personnel audit (Source: own elaboration) 


\section{Conclusion}

Inventories of methods and methodologies used in personnel audit have evolved. In essence, at each stage of their development, they reflected the needs of personnel work and personnel audit on the one hand and on the other hand they reflected the knowledge peer of individual scientific disciplines, their methodological apparatus and the methods and procedures developed by them, methods and procedures applicable to personnel audits in companies. This finding was largely confirmed by the results obtained in our realized research. For example, it was confirmed that the companies we examined, which were already at the fourth industrial revolution stage in terms of the developmental stage of personnel work, used in the personnel audit mostly a combination of basic and diagnostic methods, with an emphasis on collecting information and their evaluation using information and communication technologies. According to respondents' answers, this requirement was made with the maximum effort to objectify the personnel audit process and to limit the subjective errors of auditors in the data collection process as well as in the interpretation. The research also pointed out that companies showing elements of the Fourth Industrial Revolution in personnel auditing used a wider repertoire of mathematical statistical and predictive methods, for example to identify and express the human capital potential of a company, to identify the training needs of employees and also, for example to identify the "hidden personnel reserves" of a company, such as company in which management persisted in old approaches to personnel work and employees. Although some of the information obtained did not reach the level of representativeness and the frequency of some responses was not statistically significant enough to allow generalization, the overall empirical research has yielded many original results and findings, and has also outlined the development of methods and approaches for personnel audit. The research predicted that in the new stage, in the industrial revolution stage 5.0, which companies are facing, the importance of personnel audit will increase and at the same time the repertoire of methods used to diagnose managers' soft skills as well as non-standard methods using information communication and digital technologies. Already, the first swallows of this process, which are associated with exploiting the information potential of social networks for the needs of personnel audits, are already noticeable.

This article is a partial output of the VEGA project no. 1/0447/19. 


\section{References}

1. M. Bartekova, H. Majdúchová. Performance Potential and Development of Creative Industry: The Case of Slovakia. In 33rd International-Business-InformationManagement-Association (IBIMA) Conference (Granada, Spain, 5895-5902, 2019)(2019)

2. L. Meňovský. Controlling ako nástroj personálneho manažmentu. Personálny manažment. Bratislava, Raabe (2005)

3. M. Szarková, M. Andrejčák, N. Matkovčíková. Personnel audit as a function of personnel marketing and personnel management. Brno: Tribun EU, 2014. ISBN 97880-263-0809-6 (2014)

4. M. Szarková. Psychológia pre manažérov. Praha: Wolters Kluwer, 2016. 260 p. ISBN978-80-7552-175-0 (2016)

5. M. Vetráková. Riadenie l'udských zdrojov v ubytovacích zariadeniach hotelového typu. Bratislava: Wolters Kluwer. ISBN 978-80-8168-612-2 (2017)

6. J. Arnold et.al. Work Psychology: Understanding Human Behaviour in the Workplace. Harlow : Pearson Education Limited. 2016, 765 p. ISBN 978-1-2920-6340-1 (2016)

7. R.K.Yadav, N. Dabhade. Human Resource Planning and Audit-a Case Study of HEG Limited. Human Resource Management, 4:5 (2014)

8. J. Dušek et al. Nezaměstnanost a determinanty trhu prace v podminkach modernich evropskych ekonomik. Česke Budějovice: Vysoka škola evropskych a regionalnich studii (2017)

9. V. Bolek. Digitalizácia podnikových procesov v kontexte priemyslu 5.0. Bratislava: Fakulta podnikového manažmentu EU. ISBN978-80-225-4683-6 (2019)

10. J. Kintler. Eliminácia rizík spojených s investovaním do l’udského kapitálu podniku In: Personálny marketing a personálny manažment v organizácii. Bratislava: EKONÓM. Ed. ISBN 978-80-225-3843-5 (2013)

11. J. Anglim, V. Sojo, L.J. Ashford et al. Predicting employee attitudes to workplace diversity from personality, values, and cognitive ability. Journal of Research in Personality 83 (2019)

12. J. Dušek. Sociální kapitál a jeho vztah k rozvoji regionu. In.: Pána, J., Valášek, L., et.al.: Sociologie politiky - minulost, současnost, budúcnost. České Budejovice: VŠERS, o. p. s. 2012, p. 242-249. ISBN 978-80-87472-33.0 (2012)

13. Audit reports focused on personnel audit of examined companies from 2012 to 2014 and 2016 - 2018. Internal materials.

14. J. Kintler, Valuation of the company human capital. In 8th International Scientific Conference on Financial Management of Firms and Financial Institutions, Ostrava, Czech Republic, 342-348, (2013)

15. J. Kintler, Influence of Knowledge in the process of valuing company human capital. In International Conference on Current Problems of the Corporate Sector, Bratislava, Slovak Republic, 191-196, (2014)

16. G. W. Florkowski, R. S. Schuler, Auditing Human Resource Management in the Global Environment. Human Resource Management Journal, 5, 4 (2006) 
17. S. L. Albrecht, A. Marty, Personality, self-efficacy and job resources and their associations with employee engagement, affective commitment and turnover intentions. The International Journal of Human Resource Management 31, 5 (2020)

18. O. Lundy, From personnel management to strategic human resource management. The International Journal of Human Resource Management 5, 3 (2006)

19. I. Roper, P. Higgins, P. James, Shaping the bargaining agenda. The Audit Commission and public service reform in British local government. International Journal of Human Resource Management 18, 9 (2007)

20. M. F.R. Kets de Vries et al., The development of the Personality Audit: a psychodynamic multiple feedback assessment instrument, The International Journal of Human Resource Management 17, 5 (2007) 